\title{
The International Right To Highest Attainable Standard Of Physical And Mental Health: Evaluating Obligations Of Lithuania In Cases Of Violence Against Women
}

\author{
Laima Vaige \\ Mykolas Romeris University
}

doi: 10.19044/esj.2016.v12n23p34 URL:http://dx.doi.org/10.19044/esj.2016.v12n23p34

\begin{abstract}
The paper explores the role of the international right to the highest attainable standard of physical and mental health in the development of the legal framework in Lithuania to address violence against women. The right to the highest attainable standard of physical and mental health is entrenched under various international legal instruments. These have been ratified by Lithuania which, in 2011, also adopted a Law for the protection against domestic violence. Violence against women, including domestic violence, is undoubtedly a violation of the right to health; therefore the Lithuanian context provides an opportunity to evaluate the duties of the state in this regard more precisely. Indicators on human rights measurement have been instrumental in this evaluation.
\end{abstract}

Keywords: Gender-based violence, violence against women, domestic violence, the right to highest attainable standard of physical and mental health, human rights indicators

\section{Introduction}

It is self-evident that violence against women has very significant negative implications for their health. The World Health Organization (WHO) has indicated that women who suffered physical or sexual violence have experienced a "range of physical symptoms (problems with walking, pain, memory, dizziness, and vaginal discharge)" (WHO 2005) Physical violence is associated with various types of injuries. Women who experience violence (and most frequently, as indicated by the WHO, this is intimate male partner violence) face significant mental health challenges and may be more susceptible to suicide. In many cases violence continues during pregnancy; in a significant number of cases it may even start during pregnancy or intensifies during this period. Victims of violence also report 
induced abortions or miscarriages, as well as the risk of HIV and other sexually transmitted infections. The WHO, which launched new clinical and policy guidelines in 2013 to guide the response of the health sector, sees violence against women (VAW) as "global health problem of epidemic proportions” (WHO 2013). In 2014, the WHO also called for the development of a draft global plan of action "to strengthen the role of the health system within a national multisectoral response to address interpersonal violence in particular against women and girls and against children" (WHO 2014). The content of this plan is currently under discussion.

The EU Fundamental Rights Agency (FRA) presented its survey on violence against women aimed at identifying the scope and nature of violence against women in all 28 EU Member States (FRA 2014). The survey shows that some $49 \%$ of women in Lithuania were aware of women among their friends or family members who have been victims of domestic violence. While the overall scale of violence within Europe is difficult to measure precisely, on average $33 \%$ of women (or some 62 million individuals) are victims of violence (FRA 2014). In Lithuania, the data provided by the Police Department confirms that the vast majority of victims of domestic violence are female: in 2013, out of all persons granted victim status in the domestic violence cases, $81.7 \%$ were women, $11.1 \%$ were men and $7.2 \%$ were children (Police Department 2014). Sexual violence is also quite prevalent. For example, an anonymous survey of 300 women (who are married or have lived with partners) conducted in Vilnius Maternity Hospital showed that $80 \%$ of respondents did not know the difference between consensual sex in marriage and marital rape; 60\% had experienced sexual harassment and 30\% per cent said they had been forced into having sex with their husbands against their will (EWL 2013).

The results of European survey on violence against women showed that in Lithuania only $1 \%$ of victims sought help from the social services and $2 \%$ from crisis centres, $24 \%$ from the police. The reasons for not seeking assistance are mistrust in institutions (21\% in Lithuania, compared to an EU-wide average of $9 \%$ ), shame (25\% in Lithuania; EU average $12 \%$ ) and an unwillingness to make their case public (22\% in Lithuania; EU average 12 \%) (FRA 2014). Meanwhile victims tend to turn to the health sector even more often than the police: in case of physical violence, $15 \%$ turned to a doctor, health centre, or other healthcare institution, $11 \%$ went to a hospital, and only $14 \%$ went to the police. In case of sexual violence, the tendency to turn to medical sector is even more prevalent: $22 \%$ turned to a doctor, health centre, or other healthcare institution, $12 \%$ went to a hospital, and $15 \%$ went to the police (FRA 2014). This could lead to the conclusion that the health sector is very much involved in the fight against violence, given its 
implications for women's health. In reality, it is quite the opposite. The health sector is not directly involved in the response to domestic violence.

The paper explores the role of the international right to the highest attainable standard of physical and mental health for the development of the legal framework addressing violence against women in Lithuania. The aforementioned right is entrenched under various international legal instruments, notably: Article 25(1) of the Universal Declaration of Human Rights $^{2}$, Article 12 of International Covenant on Economic, Social, and Cultural Rights ${ }^{3}$, Article 11 of the European Social Charter, ${ }^{4}$ Article 24 of the UN Convention on the Rights of the Child ${ }^{5}$, Articles 1 and 12 of the Convention on the Elimination of all Types of Discrimination against Women ${ }^{6}$, Article 25 of the UN Convention on the Rights of Persons with Disabilities, ${ }^{7}$ and Article 20(2) of the Council of Europe Convention on Preventing and Combating Violence against Women and Domestic Violence (Istanbul Convention). ${ }^{8}$ Aside from the Istanbul Convention, each of these instruments have been ratified by Lithuania, which is also a Member State of the European Union, to which the EU Charter of Fundamental Rights ${ }^{9}$ applies fully and without reservations (including Article 35 on health care). Lithuania adopted a Law for the Protection against Domestic Violence (No. XI-1425, adopted by the Parliament on 26 May 2011). Violence is without a doubt a violation of the right to health, and this provision is an

${ }^{2}$ UN General Assembly, Universal Declaration of Human Rights, 10 December 1948, 217 A(III). Although merely a soft law instrument, the Universal Declaration has been so accepted by the global community that it can be seen as international custom. The commitment to human rights has been later entrenched in more specific international and regional treaties which required ratifications by states.

${ }^{3}$ UN General Assembly, International Covenant on Economic, Social and Cultural Rights, 16 December 1966, United Nations, Treaty Series, vol. 993, p. 3., Lithuania became a party in 2002, Valstybès žinios, 2002-08-02, Nr. 77-3290.

${ }^{4}$ Council of Europe European Social Charter, adopted in 1961 and revised in 1996. Ratified by Lithuania in 2001, Valstybès žinios, 2001-06-08, Nr. 49-1704.

${ }^{5}$ UN General Assembly, Convention on the Rights of the Child, 20 November 1989, United Nations, Treaty Series, vol. 1577, p. 3, ratified by Lithuania in 1995, Valstybès žinios, 199507-21, Nr. 60-1501

${ }^{6}$ UN General Assembly. Convention on the Elimination of All Forms of Discrimination Against Women, 18 December 1979, United Nations, Treaty Series, vol. 13, ratified by Lithuania in 1995, Valstybès žinios, 1995-09-15, No. 76-1764.

${ }^{7}$ The Convention on the Rights of Persons with Disabilities (GA resolution A/RES/61/106), adopted by UN General Assembly on 13th December 2006; entered into force on 3rd May 2008 following ratification by the 20th State Party. Lithuania ratified the Convention in 2010.

${ }^{8}$ Council of Europe Convention on Preventing and Combating Violence against Women and Domestic Violence CETS No. 210, opened for signature in 2011, entered into force in 2014, signed by Lithuania in 2013.

${ }^{9}$ Charter of Fundamental Rights of the European Union, OJ C 83/389, 2010/C 83/02. 
attempt to combine the indicators provided in different frameworks: the right to health and freedom from violence against women. Such a task has its limitations, considering the relative fragmentation of these instruments, which have been adopted by different actors and in different contexts. Sometimes the themes of health and violence are separated even within a single document (a notable example being the Beijing Declaration and Platform for Action, 1995). The idea of drawing on different sets of indicators (those designed for health, and those designed for violence) can prove to be challenging in practice. Nevertheless, it is a worthwhile methodology since states are bound by legal obligations ${ }^{10}$ to eliminate gender-based violence and ensure the right to health. An evaluation based upon indicators therefore provides a useful means of assessing national compliance with these norms. Good indicators are specific, measurable, attainable, relevant and time-framed (SMART).

\begin{tabular}{|c|c|c|c|c|}
\hline The mandate & $\begin{array}{l}\text { Title and date of } \\
\text { the document }\end{array}$ & $\begin{array}{l}\text { Types of } \\
\text { indicators/ } \\
\text { standards }\end{array}$ & The aim & The effect \\
\hline $\begin{array}{c}\text { UN Special } \\
\text { Rapporteur of the } \\
\text { Commission on } \\
\text { Human Rights }\end{array}$ & $\begin{array}{l}\text { Report of the } \\
\text { Special } \\
\text { Rapporteur Paul } \\
\text { Hunt on the Right } \\
\text { to everyone to the } \\
\text { enjoyment of the } \\
\text { highest attainable } \\
\text { standard of } \\
\text { physical and } \\
\text { mental health, } \\
2006 \text { (last version) }\end{array}$ & $\begin{array}{l}\text { Structural } \\
\text { indicators } \\
\text { Process } \\
\text { indicators } \\
\text { Outcome } \\
\text { indicators }\end{array}$ & $\begin{array}{l}\text { Measuring } \\
\text { progressive } \\
\text { realization of the } \\
\text { right to } \\
\text { enjoyment of the } \\
\text { highest } \\
\text { attainable } \\
\text { standard of } \\
\text { physical and } \\
\text { mental health }\end{array}$ & $\begin{array}{l}\text { Assessing steps } \\
\text { taking by the State } \\
\text { in meeting its } \\
\text { obligations relevant } \\
\text { to the right to health }\end{array}$ \\
\hline $\begin{array}{c}\text { UN Special } \\
\text { Rapporteur on } \\
\text { violence against } \\
\text { women, its } \\
\text { causes and } \\
\text { consequences }\end{array}$ & $\begin{array}{l}\text { Report of the } \\
\text { Special } \\
\text { Rapporteur on } \\
\text { violence against } \\
\text { women, its causes } \\
\text { and consequences, } \\
\text { Yakin Erturk. } \\
\text { Indicators on } \\
\text { violence against } \\
\text { women and State } \\
\text { response, } 2008\end{array}$ & $\begin{array}{c}\text { Institutional } \\
\text { (structural) } \\
\text { indicators } \\
\text { Process } \\
\text { indicators } \\
\text { Outcome } \\
\text { indicators }\end{array}$ & $\begin{array}{l}\text { Measuring } \\
\text { protection, } \\
\text { prevention, } \\
\text { persecution in } \\
\text { cases of } \\
\text { violence against } \\
\text { women }\end{array}$ & $\begin{array}{l}\text { Establishing VAW } \\
\text { indicators is a } \\
\text { "human rights } \\
\text { obligation" of the } \\
\text { state, based on } \\
\text { diligence principle } \\
\text { and human rights } \\
\text { case law }\end{array}$ \\
\hline
\end{tabular}

Table No.1. The key indicators used for the evaluation of obligations in VAW cases

This article analyzes the infringements of the right to the highest attainable standard of physical and mental health in domestic violence

${ }^{10}$ Moreover, indicators can also be seen as being confined merely to recommendatory guidelines for the progressive realization of state responsibilities. The ongoing debate on the lack of normativity in this area, i.e. the lack of a global Convention on VAW, and the efforts to monitor the commitments of states established through soft law instruments - resolutions, recommendations - requires a separate study. 
situations, primarily in consideration of the indicators specified by the UN Special Rapporteur of the Commission on Human Rights (2006) and the UN Special Rapporteur on violence against women, its causes and consequences (2007). Moreover, it must be noted that there are other sets of indicators and international standards that should also be taken into consideration: the EU indicators for the Beijing Platform for Action (EU Council 2014), the recommendations of the UN Committee on the Elimination of Discrimination Against Women (CEDAW) with regards to violence (CEDAW 1989, CEDAW 1992) and health (CEDAW 1999), the recommendations of the WHO (WHO 2013), the CoE minimum standards for support services (CoE 2007) and other documents. ${ }^{11}$ Due to constraints of scope of the paper, it is not be possible to analyse them all in this article. Thus the primary focus of this article is aimed at the two most relevant sets of indicators illustrated above: i.e. the indicators adopted on the right to health, and on violence against women at the UN level. Where appropriate, and as clearly indicated in the text, other binding international measures are relied upon, in order to crystalize the obligations of the state. At the end of the paper, conclusions are drawn regarding these selected indicators in relation to preventing, protecting against and prosecuting domestic violence.

\section{Structural (institutional) indicators}

The Report of the Special Rapporteur Paul Hunt on the right to everyone to the enjoyment of the highest attainable standard of physical and mental health described the structural indicators as following:

"Structural indicators address whether or not key structures and mechanisms that are

necessary for, or conducive to, the realization of the right to health, are in place. They are often (but not always) framed as a question generating a yes/no answer. For example, they may address: the ratification of international treaties that include the right to health; the adoption of national laws and policies that expressly promote and protect the right to health; or the existence of basic institutional mechanisms that facilitate the realization of the right to health, including regulatory agencies.“ (2006)

Meanwhile, the Report of the Special Rapporteur on violence against women, its causes and consequences by Yakin Erturk describes the same indicators in near-identical way, but uses the term "institutional" with a view

${ }^{11}$ In particular, the EU minimum standards for the protection of victims, which are established in the series of EU legislation (the so-called Victims' Package), see "EC actions to combat Violence against Women”, factsheet of March 2014, available at http://ec.europa.eu/justice/gender-equality/files/documents/140303_factsheet_vaw_en.pdf 
towards avoiding "confusion with the more common socio-economic usages" [of the word "structural"] (UN Special Rapporteur on violence against women, 2007). However, in essence the same outcome is required: the adoption of legal acts and ratification of international instruments. What legal instruments are required? The comparison of the indicators suggests that at least all forms of violence should be criminalised, the action plan on VAW should be introduced, and the international instruments relating to violence should be ratified, in particular, the CEDAW and the Istanbul Convention. Considering that Lithuania is also a Member State of the EU, it is clear that transposition of the relevant EU standards is also required.

As a preliminary point, Lithuania should be praised for the introduction of a comprehensive Law for the Protection against Domestic Violence in 2011 (hereinafter "the Law"). This legislation renders domestic violence to be of "public importance"; hence victims no longer have to initiate private proceedings. In the initial stages of the operation of the Law, however, there were problems with contradictory provisions, considering that the Criminal Procedure Code (CPC) has not been changed concurrently with the introduction of this legislation. The necessary amendments to the CPC were only introduced in 2013, thus a clear legislative basis for the initiation of proceedings by the state prosecutor rather than the victim was only fully established in July 2013 (amending Law No XII-502, 2 July 2013).

The Law establishes a comprehensive scheme of assistance, where the victim does not need to contact special assistance centres. Police officers transfer the information directly, and the victim is then contacted by the specialized assistance centre. Before the 2014 amendments to the Law, it was unclear whether the consent of the victim was required for such a transfer. In practice, this would be enabled only by formal written consent (Police General 2013). However, the current version of the Law provides that the police need only inform the victim of domestic violence about the procedure and transfer the data "immediately" (Article 9). With the view of balancing the interests of data protection and the interests of the victim's right to mental and physical health, the Law provides that only the most necessary data of the victim is to be transferred. The said centres do not sensu stricto "protect" the victim but provide legal, psychological, social other important welfare services. They can inform the victim of her rights and provide shelter if necessary and appropriate. However, where there is a direct threat to victim's health or life, the onus is on the system of law enforcement to ensure the protection of that person. There are two measures specific to the Law on protection from domestic violence: the obligation to move out, and the obligation not to approach. In both of these cases, the 
perpetrator's rights are limited with the view of protecting a women's right to life and health.

The Law could be criticized for omitting the definition of "genderbased violence" and failing to provide any context of inequality and subordinate status of women, which often leads to a culture of silence and denial. Though the UN Handbook for Legislation on Violence against Women indicates that the legislation on domestic violence does not have to be gender specific, it is nevertheless recommended that such legislation should "be gender-sensitive, not gender-blind" (UN Handbook 2010). Moreover, Article 16(5) of the UN Convention on the Rights of Persons with Disabilities 2006 also suggests that the states should adopt children-specific and women-specific legislation and policies against violence. At the moment, the Lithuanian laws, strategy and action plan relating to violence are completely gender-blind. State agents do not have the legislative basis to apply a gender-sensitive approach, either in protecting victims, prosecuting the perpetrators, or preventing violence. There can be no funds allocated to awareness-raising regarding stereotyping, prejudicing and subordinate view of women, if the legal acts do not recognize this as an issue. Meanwhile, under the relevant Conventions, namely the CEDAW and Istanbul Convention, "gender-based violence against women, in its various manifestations, one of which is domestic violence, must lie at the heart of all measures taken in implementation of the Convention". ${ }^{12}$ The suggested approach is certainly not being followed in this particular context.

Moreover, though the Law mentions sexual violence as one of the forms of domestic violence, the specific definition of marital / intimate partner rape is not provided for in the Lithuanian legislation. In theory, there is no basis for claiming that a spouse is exempted from liability due to his status, and there is no good reason for it to be allowed in practice. The failure to clearly underline in the legislation that this is the strict rule, was seen as a failure to fulfil the Council of Europe's minimum standards (EWL 2013). It must be noted that Lithuania is not yet a full party to the Istanbul Convention (and this Convention was used by EWL as encompassing the minimum standards), but the CEDAW Committee in 2014 also clearly recommended criminalizing marital rape in a more explicit manner (CEDAW, 2014).

\footnotetext{
${ }^{12}$ Explanatory Report of Article 2 (Scope) of the Convention on Preventing and Combating Violence against Women and Domestic Violence CETS No. 210, signed by Lithuania in 2013.
} 
Lithuania is a contracting party to the CEDAW and regularly reports to the CEDAW Committee. However, the country has not yet ratified the CoE Convention on Preventing and Combating Violence against Women and Domestic Violence (Istanbul Convention). This is also a structural/institutional indicator, listed by the Special Rapporteur on violence against women in 2007, who suggests ratification of the relevant regional conventions. It was also specifically recommended by the CEDAW Committee in its Concluding observations on Lithuania (CEDAW, 2014). The Istanbul Convention has been signed by the Minster of Foreign Affairs Linas Linkevičius on behalf of the Republic of Lithuania. Lithuania signed this Convention with a unilateral declaration that "it will apply the Convention in conformity with the principles and the provisions of the Constitution of the Republic of Lithuania” (CoE 2013). It is not clear when the Convention is to be submitted to the Parliament for ratification.

The EU legal acts relating to the protection of victims should be also implemented: the so-called "Victims' Package" includes Regulation No. $606 / 2013$ on mutual recognition of protection measures in civil matters and two specific Directives. ${ }^{13}$ The Regulation already applies directly, while the Directives must be transposed into national law. In July 2015, one of the directives (the EPO Directive) was transposed. The Victims' Directive, which is most relevant for victims' rights, is transposed by amendments which came into force in March of 2016..

Another structural indicator has only been partially fulfilled in this regard, namely the general statutory recognition of non-discrimination and gender equality (Special Rapporteur on VAW, 2007). Lithuania has established the national machinery for gender equality, including appointing an Ombudsperson on equal opportunities. It can be observed, however, that the strengthening of the institutional mechanisms, as well as VAW, have been selected as the two priority areas by the CEDAW. The Ombudsperson's position was not filled for two years, and the Ministry of Social Security and Labour only employed three people who work directly with gender equality programmes (CEDAW, 2014). The statutory recognition of gender equality issues in the context of violence is lacking, as analysed previously.

Furthermore, the action plan on VAW is required (Special Rapporteur on VAW, 2007). The national programme for implementation of the Law for the protection was adopted in 2014. A draft National Programme

${ }^{13}$ Directive 2011/99/EU of the European Parliament and of the Council of 13 December 2011 on the European protection order. OJ L 338/2. The Directive must be implemented into national law by January of 2015. Directive 2012/29/EU of the European Parliament and of the Council of 25 October 2012 establishing minimum standards on the rights, support and protection of victims of crime, and replacing Council Framework Decision 2001/220/JHA. OJ L 315/57. The Directive had to be implemented into national law by 16 November 2015. 
for the Prevention of Domestic Violence and Provision of Assistance to Victims for 2013-2020 was first drawn up in 2012 (Ministry of Social Security 2013a). It was criticized on many grounds, including being completely gender-blind, vague and non-concrete. In February 2014, a new version of this Programme was suggested (Ministry of Social Security 2014a), this time with more concrete actions envisaged. The new programme was promptly adopted despite some criticism by the CEDAW Committee (CEDAW 2014). The new programme addresses only domestic violence; therefore VAW in other areas no longer falls under any programme. This aspect, as well as the lack of reliance on the CEDAW, is a regression. However, a programme on violence is necessary both for the purposes of planning activities and budgeting, and is furthermore recommended by the CEDAW and Special Rapporteur. The aim of the programme (Government 2014a) is to ensure the prevention of domestic violence and protection of victims of domestic violence. It attempts to do so first, through raising awareness and, second, by improving the mechanism of comprehensive assistance. The adoption of the programme in general should be evaluated positively, because it opened the door to further adopt an action plan and allocate resources. The contents of the programme and subsequently, the action plan (Ministry of Social Security and labour, 2014d) are nevertheless rather restricted. The programme only addresses domestic violence and does not cover all or some forms of violence "within an explicit gender analysis", as suggested by the indicators on VAW. In fact, considering that the state focuses predominantly on domestic violence, street violence against women and girls is not addressed in any action plan.

It can also be recommended that the authorities create a “comprehensive national strategy for promoting women's right to health throughout their life span" (UN Committee on Economic, Social and Cultural Rights 2000), which would inter alia tackle violence. Such strategy does not yet exist. There is a general lack of attention to the health of women: there is no law on reproductive health and there is no sexual education programme available at schools. The provision of information and education is lacking, especially regarding sexual and reproductive health of all women, including victims of violence.

Regarding the right to health and protection against violence, the duty of health practitioners to report cases of violence (mandatory reporting) should also be considered. In Lithuania this duty is provided under the ministerial Order of 2002 (Minister of Health, Minister of Interior, Prosecutor General, 2002) and is not widely known. It can be claimed that these kinds of obligations should be provided at the level of general legislation, rather than ministerial orders. This has resulted in a position whereby hospitals will report possible incidents of violence, but other health 
practitioners (family doctors, gynaecologists etc.) do not. Moreover, there is a legislative basis for health care institutions to cooperate with specialized assistance centres (Ministry of Social Security 2012), which is also essential in cases of suspected violence.

Finally, the issue of financial allocations for the State to combat domestic violence against women should be considered. The Report of the Special Rapporteur on the Right of everyone to the enjoyment of the highest attainable standard of physical and mental health (2006) suggests considering the basic financial context, as well as the basic legal context. In Lithuania there is an issue of proportionality of the funds allocated. The insufficiency of these budgetary allocations has been criticized both by the police, the specialized assistance centres and the CEDAW Committee. The specialized assistance centres received only 25000 Litas (7280 Euros) in 2011, and there was no money allocated for the police, despite the increased costs involved. In 2012, nine specialized assistance centres received 580000 Litas (168 907 Euros), and in 2013 - 920000 Litas (267 922 Euros) (Ministry of Social Security 2014). Considering the recent amendment, which states that specialized assistance centres should provide assistance around the clock (Article 8(4), the funding should also have been adequately increased. Although some state funds have been allocated pursuant to the preventative measures provided for under Article 4 of the Law, these monies tend to be insufficient or come too late.

In consideration of unfulfilled or partially fulfilled structural indicators, the following recommendations could be drawn. First, all forms of VAW must be criminalized, including explicit definitions of marital/intimate partner rape, gender-based violence, harmful practices and stalking. The Istanbul Convention must be ratified as soon as possible, and the minimum EU standards regarding victims' rights must be transposed. The recommendations of the CEDAW regarding VAW and strengthening of the institutional gender equality mechanism should be implemented as a matter of priority. The national action plan should address all forms of VAW and not simply domestic violence. The duty of health practitioners to report violence cases should be established at a higher legislative level. Finally, proportional and timely state funding must be ensured.

\section{Process indicators}

Process indicators are created to "measure programmes, activities and interventions. They measure, as it were, State effort." (UN Special Rapporteur of the Commission on Human Rights, 2006). In other words, they "refer to policy instruments, programmes and specific interventions; actions taken by States and individuals to protect and fulfil rights." (UN Special Rapporteur on violence against women, 2007). The process 
indicators on access to justice and reporting, victim protection, prevention, and training on VAW are the most crucial (UN Special Rapporteur on violence against women, 2007).

Access to justice and reporting should encompass increased reporting rates, as well as increased rates of prosecution and conviction. Victim protection should show an increase in the index of support services, which accordingly signifies an expansion of specialized provision. Preventative efforts should include a national awareness raising campaign. Moreover, prevention of VAW should be incorporated into the general school curriculum. Finally, training should ensure that the capacity of professionals to address the needs of VAW victims is improved. (UN Special Rapporteur on violence against women, 2007).

\section{Justice and reporting}

In order to evaluate the efforts of the state, it is necessary to collect the data on the convictions of perpetrators per year, the average length of sentences, and case attrition - the percentage of cases that do not reach the court (dropped cases) or fail to receive any sanction. The duty to collect statistical data has been established in the action plan of 2014 (Ministry of Social Security and Labour, 2014d). It is clear that the numbers of reported offences, prosecution and convictions have increased. For instance, in 2010 there were 334 reported female victims of domestic violence, and in 2013 this figure had increased to 5635 women (Department of Informatics of the Ministry of the Interior, 2014). 13,1 percent of victims in 2014 were male, and 6,3 percent of suspects were female. The data on the basis of sexual orientation is not collected. In fact, the action plan does not specify which statistical data needs to be collected, and the indicator of case attrition is not highlighted anywhere in the reports. It is a very important indicator, because it measures whether these have ultimately policies had an impact. Moreover, the statistical data only measures VAW committed by a spouse, partner or cohabitant of the victim. Though it is important data to collect, other types of VAW should also be addressed. They must be collected in a segregated manner and not lumped together. In that regard, the administrative data from the national criminal justice system should follow the global statistical indicators on violence against women, as adopted in 2010 (UN Statistical Commission and Statistics Division, 2010).

Moreover, the most recent database on gender based violence (EIGE 2016), presented by the European Institute of Gender Equality (EIGE), must be mentioned. The database draws on harmonized and non-harmonized data and distinguishes between these forms of VAW: sexual violence, intimate partner violence, stalking, homicide, trafficking in humans, non-sexual harassment and bullying, and harmful traditional practices. By the types of 
violent act, the database distinguishes between: sexual violence (rape, other sexual assault, sexual harassment), economic violence, physical, psychological violence, stalking, female genital mutilation, and trafficking in humans. The data is also segregated to reflect on the relationship of the perpetrator and victim: intimate partner violence, violence inflicted by family members, violence inflicted in workplace, and other.

\section{Victim protection}

As noted above, there are two protective measures specific to the Law on protection from domestic violence (protection orders): the obligation to move out of the home shared with the victim, and the obligation not to approach the victim. In both of these cases, the victim may stay at home and the perpetrator is kept at a distance. However, $11 \%$ of victims faced repeated violence because of a lack of protection in 2012-2014 (State Audit 2015). There have been very disturbing cases of murders in 2013, whereby women were killed despite having been granted protection orders. For instance, in March 2013, a woman called for help saying that her violent husband had returned despite a protection order (Lietuvos Rytas 2013). There was no response from the police. After six hours, her brother informed the emergency services that the victim was dead. A few similar cases occurred in March 2013, when two women were murdered, despite the neighbours' calls to the police, and in June 2013, when a woman was murdered by her husband who was not supposed to approach her. It must be ensured that domestic violence calls are never placed into the "insignificant" category, classified as category $C$ in the police system. The special report of the State Audit Office revealed that no protective measure were appointed in almost half of the cases and $11 \%$ of victims subsequently faced repeated violence (State Audit 2015). The data on application of protection orders in cases of VAW should be collected. Currently, it is known at the level of Prosecutor's office but not to the general public. To my knowledge, in some of the regions, protection orders have never been adopted.

It must also be ensured that breach of protection orders are treated seriously. The debate still continues as to whether amendments of the Criminal Procedure Code are necessary to harmonize the procedure on applying the protection orders and in order to ensure that breaches are treated seriously. For instance, it could be suggested that the breach of a protection order should be treated as a breach of any other court order - which under Article 245 of the Criminal Code is seen as a criminal offence. At the moment this is not the common practice, i.e. the breach of a protection order is not treated as a criminal offence. Instead, it is provided under Article $132^{1}$ part 3 of the Criminal Procedure Code that the perpetrator is warned that if he disregards protection measure, another measure may be applied (for 
instance, detention). This results in much lighter treatment of protection orders than other court orders in the criminal justice system.

Furthermore, protection orders only last until the end of the court proceedings. It often happens that after a court decision, the convicted is immediately released on parole. However, in some instances, it is also necessary to apply protection orders after the decision of the court (State Audit 2015).

Regarding the breach of protection orders, court practice is alarming. For instance, in January 2016, the Regional Panevėžys Court adopted a decision (final in that case, no. 1A-24-581/2016) to reject he prosecutor's application regarding the breach of protection order. The case concerned an elderly woman, beaten by her son. Protection order not to approach was breached, the son returned to mother's home. The court considered that the fact that the mother consented to his return home denied the gravity of his actions, which meant that a breach of protection order is not a crime and thus is not punishable. In a few weeks after the said decision, the son murdered his mother. The decision must be critisized as very bad practice, which attempts to make the victim solely responsible for her own protection. Meanwhile, according to ECtHR practice, once the act of violence (or even threats) becomes known to state authorities, they must ensure that victims right to life is protected (Opuz v. Turkey). Moreover, the Supreme Court did not formulate a good practice either. In another case (No. 2K-19-296-2016) regarding the breach of protection order, it found that the breach was a criminal offence - but then summarized sanctions in such manner, that the breach was mended into sanctions. Thus, the recognition of its breach did not result in any consequences. Therefore, in accordance with this practice, the courts are free to treat breaches of protection orders as insignificant.

Specialized assistance centres mainly provide the functions of informing and consulting with the victim and not the function of protection. The initial consultation is undertaken by telephone, and then the next appointment is made. Thus it is not reasonable to require these centres to work 24/7, as provided for by Article 8 (4) of the Law (the said requirement entered into force from 2016). It is suggested instead that there should be a greater provision of shelters and drop-in centres (CEDAW 2014), which are still lacking and may be necessary in certain situations for the purposes of victim protection. Although the obligation to move out from the common household partially solves the issue of the safety of the victim, in certain situations shelters or drop-in centres are still necessary. Notably, they are required both the Istanbul Convention and CEDAW recommendations for Lithuania. 


\section{Prevention of violence}

The timely provision of information to specialized assistance centres must be ensured in order to avoid repeated incidences of violence. An analysis of the numbers of victims referred by the police and the overall number of persons who ultimately received such services (Ministry of Social Security 2014), clearly reveals that the centers do not always receive the necessary information from the police. Often the victims apply for help later. Sometimes the police officers provide information following a significant delay, which may even result in death of the victim or the suicide of the perpetrator.

A reconciliation (mediation, or restorative justice) procedure is still widely used in domestic violence cases during both the pre-trial investigation and trial stage, without taking into account the specific nature of the crime of domestic violence and its repetitive pattern, and without a detailed assessment of the possible risk and danger to the victim's health. For instance, the research of Human Rights Monitoring Institute in 2014 revealed that all of the interviewed women were offered reconciliation with the perpetrator, both during the pre-trial stage and at the court (HRMI 2014). At the moment mediation in domestic violence cases is even praised as "good practice.”(Venckevičienè, Čepas 2013). Meanwhile, the UN Handbook on Legislation on Violence against Women states that legislation should "explicitly prohibit mediation in all cases of violence against women, both before and during legal proceedings.” (UN Handbook 2010). The EU standards allow for mediation but this is restricted by the obligation to use objective criteria in order to determine the types of offences for which the Member States consider mediation to be unsuitable (Gueye and Salmerón Sánchez 2011). It is doubtful whether serious domestic violence can be effectively met with mediation, but it might be useful in cases involving minor (under age) perpetrators (Vaigè 2013). Compulsory mediation is also clearly forbidden under the Istanbul Convention (Article 48).

The cautionary approach to mediation in cases of intimate partner violence must be evaluated positively. Alternative dispute resolution cannot work in situations with clear power imbalance. For instance, one of the parties had suffered serious psychological and physical damage, e.g. had been raped, beaten, possibly disabled, family member had been killed or committed suicide as a result of long-term violence, and the other party avoided any punishment, even after such violence became known to state authorities. These are the facts of cases analysed by the European Court of Human Rights or by the CEDAW Committee: e.g. Opuz v Turkey (2009), Jallow v. Bulgaria (2012), and many others. Alternative dispute resolution can only work in situations of mutual violence, short-term violence, and violence which does not involve coercive control of the partner. For that 
purpose, Victims' Directive in its preamble proclaims that “[r]estorative justice systems [...] can be of great benefit to the victim, but require safeguards to prevent secondary and repeat victimisation, intimidation and retaliation.” Article 12 of the Directive provide for conditions and safeguards for the use of restorative justice. In all situations, the states must ensure that victims' safety comes first.

In addition, it can be observed that restorative justice systems are more developed in some legal system than others. For instance, the so-called undertakings - voluntary promises of the perpetrator - have been employed in particular in common law systems as a remedy or supplement to available measures in cases of domestic violence. However, they do not seem to work well for instance in Georgia, as shown by case of $X$ and $Y v$ Georgia (2015), where police officers took undertakings from the perpetrator and acted as mediators. Considering that it was all that they did, violence continued and impunity was fostered. The aspects of victim's protection and prevention of repetition of violence are of primary importance. In addition, prosecution and punishment are also important, especially considering that they may help prevention and protection objectives.

Another closely connected issue is the proportion of state funding of the NGO sector (specialized assistance centres) and state/municipal crisis institutions. Notably, the state institutions such as municipality crisis centres, are those which tend to suggest mediation. Recently more municipal crisis centres have been opened with significant funding from municipal budgets. Such funding is never available for NGOs. There is also a heavy reliance on funding from the EU structural funds. Regarding specialized assistance centres, the planned investment from the state budget is less than one third of the planned funding from the EU funds (Ministry of Social Security 2011). In order to show the state's commitments to combatting domestic violence have been met, it is important that the state and municipalities advance initiatives to reach out to victims and invest in civil society organizations that are closest to them.

The fact that prevention is often not taken seriously can be seen by the sporadic financing of such activities. Twenty-eight NGOs received funding aimed at “decreasing violence against women” in 2013 (Ministry of Social security 2013), with the view of providing prevention and continuing support services. The sums allocated ranged from LTL 3,600 (EUR 1,042) to LTL 42,500 (EUR 12,308). The results came in the middle of October and the funds arrived in November, which actually left just two months for project implementation (Center for Equal Advancement 2013.)

The regulation on the activities of the specialized assistance centres (Ministry of Social Security 2012) is a very brief document. There is no system for monitoring the quality of the services provided, although there are 
some guidelines as to the qualifications required of the persons employed at such centres. They should have education in the field of social sciences, preferably in psychology, social work or law. It is clear from the text that specialized assistance centres are not expected to provide health care services, but upon the request of the victim, they may acts as the intermediaries for procuring medical assistance, and they should cooperate with health care institutions (points 6.3 .5 and 6.4 of the regulations).

In 2014 the Ministry of Social Security and Labour initiated discussions towards closing the National Programme of Equal Opportunities for Women and Men (Ministry of Social Security 2014b). Women's NGOs and human rights organizations saw the proposed policy developments as a huge step backward, excising gender equality from the national policy agenda and accordingly having a negatively impact upon the sustainability of the national institutional mechanisms (CEA 2014). This national programme on equal opportunities (which was subsequently prolonged), is not specifically aimed at addressing domestic violence - but it shows that the national authorities have contemplated the removal the women's rights issues from the political and legal agenda altogether. Although the last draft programme mentions that society should be taught inter alia about "gender role stereotypes” (Ministry of Social Security 2014a), a stronger stance is needed for the purposes of preventing VAW.

\section{Greater involvement of the health sector}

The UN Special Rapporteur on violence against women underlined the significance of the involvement of medical sector in particular, (UN Special Rapporteur on VaW, 2007). First, she noted that the access to treatment for immediate injuries must be ensured, which is indeed provided for all residents of Lithuania. Trained forensic examiners are also available and services are provided free of charge, if the expertise is ordered by the state official (notably, prior to the Law, women had to seek them themselves and pay for them). However, the use of routine enquiries to identify violence at a preliminary stage, which was also recommended by the Special Rapporteur, is not currently undertaken in Lithuania. There are no data on access to emergency contraception, nor safe abortions and the treatment of sexually transmitted infections/HIV for the victims. There is some discussion that involves recognition of VAW as an underlying cause of mental health problems: notably, the quantitative and qualitative study of the Institute of Hygiene (Institute of Hygiene 2013). However, there are no data on safe outand in- patient provisions for the survivors with mental health problems.

There is a significant problem with the lack of coordination of the provision of health care services to victims of domestic violence. Article 2(3) of the Law briefly mentions that assistance should include "health care" 
services, provided by the state, municipality institutions or NGOs. The programme on activities of specialized centres does not mention medical or health care services at all (Ministry of Social Security 2011). It should be the state institutions - those that provide the necessary first aid and those that provide regular health care services - that also provide health care services for victims of domestic violence. However, their role is not mentioned in the Law or any subsequent acts. There is one amendment to the Law, which specifies the role of the National Forensic Service. Under Article 5(6), the Law now establishes that the Service must provide an assessment of the damage to health and its make expert conclusions immediately in domestic violence cases. This is a positive development. The Ministry of Health is not mentioned among ministries responsible for monitoring of implementation in the area of domestic violence (Ministry of Social security and labour. 2014c).

There are no legal provisions related to violence which would be aimed at health care institutions, except for the aforementioned duty of the health care practitioners to report injuries sustained by possible criminal acts (Ministry of Social Affairs 2002). The overview report of domestic violence by the Institute of Hygiene is primarily aimed at health care policy creators (Institute of Hygiene 2013). Although there is a limited availability of this report (it is only available in libraries and at the Institute), it lays down the first steps towards future developments, notably by evaluating the extent of damage for victims' health and providing general recommendations. It is clear that there should be a strategy for involving the health care sector in a meaningful sense -not simply "participation in the meetings" with specialized centres for inter-institutional cooperation (as provided under Regulations, point 11).

The research of the Institute of Hygiene involved a survey of 89 women and detailed interviews with 6 women in 2012. The research showed that women only accessed the medical sector when it was necessary. The level of depression was average, but also ranged depending on the social class and other factors (education, employment, financial independence). The most common feelings experienced were helplessness, anger and fear. The said study provides recommendations to the Ministry of Social Security and Labour, as well as institutions providing assistance. However, recommendations on any involvement of the health sector are lacking.

There are other efforts at a national level that ought to be recognised in this regard. In November 2013 a representative of the Ministry of Health of Lithuania acknowledged that "health sector can provide a vital role in domestic violence" and after reviewing the available framework, recognized that "this is not enough" (Astrauskiene 2013). She suggested that the health sector should prioritize and do more in this area, especially concerning 
prevention. Another important effort was made with the meeting at the Ministry of Health in April 2014, at which health practitioners and policy makers discussed the methods for identifying and preventing domestic violence (Ministry of Health 2014). It was suggested that violence against pregnant women should be monitored and documented in an adequate form (No. 111). The issue of training was also discussed. The approval of the procedure for monitoring any possible violence against pregnant women is a very tangible outcome. However, such monitoring should be extended also to women who are not pregnant.

At the moment, training related to domestic violence is only provided to police officers and prosecutors under the Law. Training for health care providers is necessary - in fact, this should be integrated into the basic curriculum for undergraduate medical students. Training needs to be multicomponent and interactive, and to cover such issues as recognizing violence, procedure of clinical inquiry, confidentiality duty, documentation and referral procedures. At the meeting at the Ministry of Health in 2014, it was observed that the Vilnius University curriculum includes a programme enabling medical personnel to recognize signs of violence, and the Lithuanian University of Health sciences (LSMU) also plans to start a similar initiative. It was also suggested that previous graduates, such as gynaecologists, could undertake further professional development courses on recognizing violence against pregnant women. These and other initiatives should be praised. Other notable developments include the translation of valuable guidance for health practitioners dealing with intimate partner violence (University of Helsinki 2006) and an upcoming project which will involve surveying victims about their mental health, initiated by LSMU doctoral student in cooperation with specialized assistance centres. However, it is also clear that an increased inter-sectoral approach is necessary. Considering the "ethical concerns about routine identification of women who need help when the health-care system is unable to provide appropriate assistance", which are sometimes raised by the health workers (UN General Assembly 2006), the health sector should work closely with the centres of specialized assistance.

Considering that women who face violence are more likely to contact their doctors or other health care institutions than the police (FRA 2014), the health care sector should indeed have a greater degree of involvement. The role of the health care sector could include, for example, provision of quality services to victims, collecting data on prevalence, risk factors, health consequences, informing the police and document violence, preventing violence by implementing prevention programmes, and advocating for domestic violence as a health issue (Lazdane 2013). Indeed, the minimum standards as recommended by the 
WHO are that health providers should be trained to ask about violence; there should be standard operating procedures, consultations should be private and confidential, there should be a referral system to specialized assistance centres, and finally a comprehensive response to sexual violence must be developed (WHO 2013). The UN High Commissioner for Human Rights also mentions training of health care professionals, and also stresses that victims of VAW have "the right to adequate reparation and rehabilitation that covers their physical and mental health" (UN High Commissioner for Human Rights 2008).

Great expectations are connected with the agenda of the WHO in this area. Notably, the draft Global plan of action to strengthen the role of the health system in addressing interpersonal violence, in particular against women and girls, and against children was opened for discussion (WHO 2015). Notably the draft plan, which is currently under discussion, also envisages the development of a set of global indicators. Although at present these indicators are still at a very preliminary stage and the WHO suggests abstaining from citing the said discussion paper altogether, it can nonetheless be predicted that they will largely interconnect the indicators used in this paper (in particular, see the Table in the Introduction). Although the said plan is only a discussion paper at the moment, it shows a clear shift towards a greater involvement of the health sector on the basis of multi-sectoral approach. Although the health sector has its particular functions, it can be invaluable in both prevention of VAW, as well as mitigating negative consequences to health, both by providing health services and referrals to specialized assistance (WHO 2015). Even prior to the finalization of plan, national governments can request the assistance of the WHO in developing national responses of the health sector to VAW (WHO 2014).

In consideration of process indicators, these overall recommendations could be drawn. First, a State-funded national programme should be provided, which would include working with the police, judiciary, and the health care sector to develop greater awareness of and sensitivity to domestic violence and gender-based violence. State-funded shelters, drop-in centres and a sufficient number of specialized assistance centres must be available, in order to provide quality services, which would also be available to ethnic minority women and women from socially-economically marginalized groups and regions and women in same-sex relations. A State-funded prevention programme is needed which focuses on the elimination of prejudice and gender stereotyping (with due regard that acts of domestic violence are often based on "traditional attitudes by which women are regarded as subordinate to men.” (CEDAW 1992). A comprehensive system of coordination, monitoring and evaluating of health-sector initiatives to 
combat domestic violence and gender-based violence must be adopted (WAVE 2012). In so doing, particular regard must be given to the recommendations of the Special Rapporteur on VAW: for instance, the use of a routine enquiry to identify violence at an early stage should be discussed and female-survivors of domestic violence must have access to mental health and reproductive/sexual health services.

\section{Outcome indicators}

Outcome indicators are created to "measure the impact of programmes, activities and interventions on health status and related issues." (UN Special Rapporteur of the Commission on Human Rights, 2006). They "document the realization of rights", and are therefore the most difficult to measure considering that human rights are interconnected (UN Special Rapporteur on violence against women, 2007). The Special Rapporteur on violence against women proposes three outcome indicators: measuring VAW, which also requires measuring grave incidents of VAW, the rates of femicide, and the indicator of social tolerance (of VAW).

The impact of the adopted policies is difficult to measure. For instance, has further training indeed changed the way in which health practitioners operate, enabling them to challenge prejudices? Do court sentences leave the victim safe and empowered, or does it make her life more difficult (for example by imposing an obligation on the perpetrator not to change their place of residence, or to stay at home during evenings)? In most cases, domestic violence will not end in the imprisonment of the perpetrator; he may be released on probation, and protective measures will no longer apply. The victim may feel disappointed with the outcome of the case. She may see that the perpetrator is "released by the court", although conversely the justice system feels that justice has been effectively served.

Lithuania has lost two cases before the European Court of Human Rights for failing to protect women against repeated incidents of domestic violence. In both cases, the Court found violations of Article 3 of the European Convention on Human Rights, a provision which provides protection against torture, inhuman and degrading treatment (Valiuliene $v$ Lithuania 2013, D.P. v Lithuania 2013). The case of Valiuliené v. Lithuania concerned a Lithuanian woman who was beaten 5 times in a period of approximately one month by her Belgian partner. No prosecution ensued. The European Court found a violation of Article 3 but in principle refused to take a gender-sensitive approach and did not find discrimination in the refusal of the Lithuanian authorities to prosecute. This position was criticized in the concurring opinion by Judge Pinto de Albuquerque, who saw it as a missed opportunity to set a precedent based on a principled reasoning and to manage the disparate jurisprudence under the Convention. Meanwhile, Judge 
Jočienè (from Lithuania) dissented, saying that the injuries were largely superficial and were: "without any lasting consequences and did not result in her being unfit to work." (Valiuliene $v$ Lithuania 2013). The case of D.P. $v$ Lithuania resulted in decision to strike out the case due to the Government's acknowledgement that Article 3 was infringed. This case involved an instance of even more significant violence. Overall it can be said that the state's acknowledgement of the problem is noteworthy. However, national courts, especially at first instance, do not tend to apply or demonstrate an awareness of international standards. For instance, there has never been a reference to the CEDAW Convention and the related cases under it, as recognized at the state level (Government 2014). References by the Lithuanian judiciary to the European Convention on Human Rights are also seldom made, and not thus far in cases of domestic violence.

Regarding data-collection, Directive 2012/29/EU urges Member States to communicate data to the European Commission not only on the number and types of reported crimes, and the number of victims, but also the age and gender of victims. This data should be collected centrally. However, the decreasing numbers of reported instances of domestic violence should not be seen as a very reliable indicator. Domestic violence is a latent crime, and decreased numbers may also show the disillusionment of the victims with the justice system, as mentioned above and a consequential reluctance to engage with the system. Moreover, the Ministry of Internal Affairs had opened discussions towards imposing higher fines for so-called false calls and reports (Ministry of the Interior 2014). The underlying idea behind this prospective policy is that the police should either see the basis for a criminal investigation, or impose an administrative fine upon the person who made the report. For instance, if a victim refuses to testify, s/he would be punished with a fine up to 3000 Litas (873 Euros). Rather than streamlining the system, such measures might further undermine it and increase the latency of the crime.

It is also advisable to monitor which efforts and initiatives have been effective and which have not. The general problem with evaluation of national programmes is that even if such an evaluation does take place, it remains invisible and is essentially undertaken by the same institution: i.e. the effectiveness of the programme that is implemented by the Ministry of Social Security and Labour is evaluated by the same Ministry, and not by an outside auditor. A positive development in this regard is the report of State Audit Office, presented in 2015. However, it must be noted that this report focused only on the work of the police and specialized assistance centres.

In consideration of outcome indicators, these recommendations could be drawn: the progress made and the lessons learned should be monitored, i.e. statistical changes of the numbers of arrests of perpetrators per year; 
average length of sentences; numbers of trained police/ prosecutors, judges, and health practitioners. For the purposes of monitoring the instances of grave violence, the data must be collected on the proportion of females who have experienced grave violence in the past 12 months, the proportion of females who have ever experienced grave violence, femicide index and trends in femicide deaths. Finally, the social tolerance indicator must be monitored. Asking questions: "is there a willingness by state actors, the medical sector and the society as a whole to intervene?" and "what are the evidence of decreased tolerance of violence against women and domestic violence?” could be useful. Considering that health care centres, other health institutions, and hospitals are the first institutions that victims contact after incidents of violence, efforts should be made to ensure that they are not the last.

\section{Conclusion}

The framework of structural, process and outcome indicators of the right to enjoyment of the highest attainable standard of physical and mental health offers a degree of promise towards developing a coherent system for the domestic implementation of relevant international legal obligations related to all forms of violence against women, including domestic violence. These obligations are supposed to be considered in accordance with the principle of progressive realisation.

Lithuania can be praised for adopting the Law on Protection against Domestic Violence in 2011 and taking progressive steps to improvement of the situation of victims. Although the legislative basis should be further elaborated (to include or specify certain definitions, as well as duties of the relevant stakeholders), progress is certainly being made. Nevertheless, some areas require urgent attention: in particular considering the necessary preparatory work for the ratification of the Istanbul Convention on preventing and combating violence against women and domestic violence and the further implementation of EU standards. The state should ensure proportionate and timely state funding, improve the Law to include definitions of marital rape, gender-based violence, and provide for higher level of involvement of health practitioners. In particular, the involvement of the health sector is significant regarding process indicators. A comprehensive system of coordinating, monitoring and evaluating health sector initiatives in response to violence should be adopted. It could include the use of routine enquiries to identify violence and ensure that female survivors of domestic violence are accorded access to adequate mental health and reproductive/sexual health services. The recognition that violence is a significant cause of mental health problems is necessary not only in studies and articles, but also at the state level. 
Further institutional and regulatory frameworks need to be created: not least the appointment of a coordination centre for specialized assistance centres and the adoption of a national programme on all forms of violence against women. The programme should include inter-sectoral cooperation between the police, judiciary, and the health care sector to develop greater awareness of and sensitivity to gender-based violence. Moreover, the adoption of the programme directed in particular at the health of women during their lifespan and focusing on violence is recommended. Even prior to the adoption of the global plan of action to strengthen the role of the health system in addressing interpersonal violence, in particular against women and girls, states can ask the WHO for assistance in developing national plans involving the health sector.

In order to monitor the progressive realization of rights, data must be collected on the proportion of females who have experienced grave violence in the past 12 months, the proportion of females who have ever experienced grave violence, femicide index, and trends in femicide deaths. The indicator of social tolerance of violence must also be observed. The fight against violence is only effective if state actors demonstrate a clear willingness to intervene, are no longer tolerant of all forms of violence against women, and acknowledge its major effects on the health of their female citizens.

\section{References:}

Astrauskienè, A. 2013. Eliminating violence against women in Europe. Health sector. Ministry of Health of the Republic of Lithuania. Presentation at conference Eliminating Violence against Women in Europe Intersectoral Approaches and Actions. 26 May 2013. Vienna. Available at http://eige.europa.eu/sites/default/files/Plenary\%204_05_AUDRONE\%20AS TRAUSKIENE.pdf. Last accessed 2016-02-10.

CEDAW. 1989. General Recommendation No. 12 (eighth session, 1989)

CEDAW. 1992. General Recommendation No. 19 (eleventh session, 1992).

CEDAW. 1999. General Recommendation No. 24 (Women and Health, 1999).

CEDAW. 2014. Concluding observations of the Committee on the Elimination of Discrimination against Women: Lithuania. CEDAW/C/LTU/CO/5.

Center for Equality Advancement (CEA) (Lygiu galimybiu pletros centras), Communication with women's NGO, 29 October 2013, 25 November 2013, 19 December 2013.

Council of the European Union 2014. Council conclusions '20 year review of the implementation by the Member States and the EU institutions of the Beijing Platform for Action’, Brussels, 11 December 2014. 
CoE. 2013. Declaration contained in a Note Verbale from the Ministry of Foreign affairs from Lithuania, dated 6 June 2013, handed over the Secretary General at the time of signature of the Instruments, on 7 June 2013.

D.P. v. Lithuania, ECHR, Strasbourg, No.27920/08, 22 October 2013.

Department of Informatics of the Ministry of the Interior, 2014. Available at: http://www.ird.lt/ Last accessed 2016-01-12.

EIGE, 2016. Gender statistics database: Gender based violence. Available at http://eige.europa.eu/gender-statistics/dgs/browse/ta/ta_gbv. Accessed 2016$01-20$

EWL. 2013. EWL barometer on rape in the EU 2013. June 2013.

FRA. 2014. Violence against women: an EU wide survey. ISBN 978-929239-342-7

doi:10.2811/62230.

Gueye and Salmerón Sánchez. 2011. CJEU Joined cases C483/09 and C1/10. Government. 2014. Replies of Lithuania to the list of issues in relation to the fifth periodic reports of Lithuania. 16 January 2014. CEDAW/C/LTU/Q/5/Ad.d.1

Government of the Republic of Lithuania. 2014a. Valstybinè smurto artimoje aplinkoje prevencijos ir pagalbos teikimo nukentejusiems asmenims 20142020 metu programa. (National Programme for the Prevention of Domestic Violence and Provision of Assistance to Victims for 2014-2020.) Available at

http://www3.lrs.lt/pls/inter3/dokpaieska.showdoc_l?p_id=471939\&p_tr2=2. Last accessed 17 January 2016.

Human Rights Monitoring Institute (HRMI). 2014. Nusikaltimų aukų teisių direktyva: naujas požiūris ị artimujų smurto aukas (Victims rights' Directive: new approach to domestic violence victims). Produced together with the Institute of Law and the Centre for Equality advancement.

Institute of Hygiene. 2013. Smurtą artimoje aplinkoje patyrusių moteru gyvenimo kokybès ir emocinès būsenos bei pagalbos prieinamumo Lietuvoje vertinimas. (Evaluation of the quality of life, emotional state and access to assistance to women who had experienced domestic violence in Lithuania). Higienos institutas, „Mokslo darbai“ Nr. 9, Vilnius, 2013 m.

Jallow v. Bulgaria, 23 July 2012, CEDAW/C/52/D/32/2011.

Lazdane, G. 2013. Evidence gathering: data in the European region. WHO. Presentation at Conference Eliminating Violence against Women in Europe Intersectoral Approaches and Actions. 26 May 2013. Vienna. Available at http://eige.europa.eu/sites/default/files/01_Plenary1_GLazdane_Session1.pdf Last accessed 2016-01-21.

Lietuvos rytas. 2013. 'Visuomenininkai niršta - moterys namuose užmušamos dèl valstybès vangumo' By S. Purytė. (Activists enraged women are killed at home due to state's ignorance), 25 March 2013, 
available at: www.lrytas.lt/lietuvos-diena/aktualijos/visuomenininkai-nirstamoterys-namuose-uzmusamos-del-valstybes-vangumo.htm. Last accessed 2016-01-21.

Minister of Health, Minister of the Interior, Prosecutor General. 2002. LR sveikatos apsaugos ministro, LR vidaus reikalu ministro ir LR generalinio prokuroro ịsakymas Dėl informacijos apie asmenis su kūno sužalojimais, kurie gali būti susiję su nusikaltimu, teikimo. (Order on provision of information about persons with bodily injuries, which may be connected with crimes). 28 January 2002. No. 55/42/16.

Ministry of Health. 2014. Press release. Tartasi kaip medicinos darbuotojai galètų prisidèti mažinant smurto prieš néščiąsias grèsmes. (Discussion on assistance of medical workers to decrease the risks of violence against pregnant women). Available at sam.lrv.lt . Last accessed 2016-01-20.

Ministry of the Interior. 2014. Press release. VRM siūlo didinti nuobaudas už melagingus skambučius 3-6 times (VRM suggests increasing sanctions for false calls by 3-6 times). 20 May 2014. Available at: https://vrm.lrv.lt/lt/naujienos/vrm-siulo-didinti-nuobaudas-uz-melagingusskambucius-i-bpc-nuo-3-iki-6-kartu Last accessed 2016-01-22.

Minister of Social security and labour, Minister of the Interior and Minister of Health. 2011. LR Socialinès apsaugos ir darbo ministro, LR Sveikatos apsaugos ministro ir LR Vidaus reikalu ministro isakymas dèl specializuotos pagalbos centru programos patvirtinimo, (Order on the approval of specialized assistance centres programme), No. A1-534/V-1072/1V-931, 19 December 2011. Available at: www3.lrs.lt/pls/inter3/dokpaieska.showdoc_l?p_id=415786\&p_query=speci alizuotos\%20pagalbos\%20centr\%F8\%20programos\&p_tr2=2. Last accessed 2016-01-15.

Ministry of Social security and labour. 2012. Isakymas Dèl Specializuotos pagalbos centru veiklos aprašo patvirtinimo (Order on approval of the regulations on activities of the specialized assistance centres regulations). $2012 \mathrm{~m}$. gegužès $7 \mathrm{~d}$. Nr. A1-227. Point 6.4. Available at http://www3.Irs.lt/pls/inter3/dokpaieska.showdoc_l?p_id=424133\&p_query= specializuotos\%20pagalbos\%20centr\%F8\%20veiklos\%20apra\%F0as\&p_tr2 $=2$. Last accessed 2015-11-12. The new version of the Order (in force from 2016) also includes the same point at 7.7.

Ministry of Social security and labour. 2013. Projektų, skirtų igyvendinti Valstybinès smurto prieš moteris mažinimo strategijos priemones, atrankos konkurso rezultatai (Results of the contest of projects on implementation of National strategy for reducing violence against women), 15 October 2013. 
Ministry of Social security and labour. 2013a. The Social report 2012-2013, P.70. Available at http://www.socmin.lt/en/social-report.html last accessed 2016-01-12.

Ministry of Social security and labour. 2014. Programa „Socialinės aprépties stiprinimas" (Program on strengthening of social inclusion) Priemone „Igyvendinti LR apsaugos nuo smurto artimoje aplinkoje ịstatymą ir specializuotos pagalbos centru programos priemones". (Measure on Implementation of the Law on Protection against Domestic violence and measures on specialized assistance centres).

Ministry of Social security and labour. 2014a. Valstybinè smurto artimoje aplinkoje prevencijos ir pagalbos teikimo nukentejusiems asmenims 20142020 metu programa. (Draft National Programme for the Prevention of Domestic Violence and Provision of Assistance to Victims for 2014-2020). Available http://www.lrs.lt/pls/proj/dokpaieska.showdoc_l?p_id=223897\&p_fix=n\&p_ gov $=n$. last accessed 2014-05-22.

Ministry of Social security and labour. 2014b. Press release. Moteru ir vyru lygių galimybių komisijos posèdyje aptarti aktualūs klausimai, (Relevant questions discussed at the hearing of the Commission of Equal opportunities for women and men), 24 April, 2014 available at http://www.socmin.lt/lt/naujienos/pranesimai-spaudai/moteru-ir-vyru9ddr.html last accessed 2015-125-22.

Ministry of Social security and labour. 2014c. Valstybinès smurto artimoje aplinkoje prevencijos ir pagalbos teikimo nukentejusiems asmenims 20142020 metų programos igyvendinimo vertinimo kriterijų ir jų reikšmių sąrašas. (Evaluation criteria for the implementation of National Programme for the Prevention of Domestic Violence and Provision of Assistance to Victims 2014-2020). Available at http://www.lrs.lt/pls/proj/dokpaieska.showdoc_l?p_id=223899\&p_org=\&p_f $\mathrm{ix}=\mathrm{n} \& \mathrm{p} \_$gov=n. Last accessed 2015-12-16.

Ministry of Social security and labour. 2014d. Dèl Valstybinès smurto artimoje aplinkoje prevencijos ir pagalbos teikimo nukentejusiems asmenims 2014-2020 metu programos igyvendinimo 2014-2016 metu veiksmų plano patvirtinimo. (Action plan for implementation of the National Programme for the Prevention of Domestic Violence and Provision of Assistance to Victims 2014-2016). Available at http://www3.lrs.lt/pls/inter3/dokpaieska.showdoc_l?p_id=483188. Accessed 2015-12-12.

Opuz v. Turkey [2009] ECHR 33401/02 (9 June 2009). Police General. 2013. Policijos Generalinio komisaro 2013 kovo 7 d. isakymas "Dèl apsaugos nuo smurto artimoje aplinkoje ìstatymo 
igyvendinimo " (Order on implementation of the Law on protection against domestic violence), No. 5-V-196, 7 March 2013.

Police Department. 2014. Policijos departamento prie vidaus reikalu ministerijos duomenys susiję su smurtu artimoje aplinkoje. Statistika. (Statistical data of the Police department on domestic violence). Available at http://www.bukstipri.lt/lt/statistika. Accessed 2016-01-13.

State Audit Office, 2015. Apsaugos nuo smurto artimoje aplinkoje organizavimas (Managing protection from domestic violence). National audit report. Published 5 May 2015. No. VA-P-40-1-8.

University of Helsinki. 2006. Partnerio smurto problemos sprendimas rekomendacijos néščiųų, gimdyvių ir kūdikių priežiūros specialistams. (Solution of intimate violence - recommendations to specialists working with pregnant women, women who gave birth and childcare specialists). Produced by Sirkka Perttu, Verena Kaselitz. Available at http://www.hyvan.helsinki.fi/daphne/pdf/Addressing_Intimate_Partner_Viol ence_Lithuanian_Version\%20.pdf Last accessed 2016-01-21.

United Nations (UN). 2010. Handbook for Legislation on Violence against Women, 2010, available

at: www.un.org/womenwatch/daw/vaw/handbook/Handbook\%20for\%20legislat ion\%20on\%20violence\%20against\%20women.pdf. Last accessed 2016-0107.

UN General Assembly, 2006. In-depth study on all forms of violence against women, Report of the Secretary-General, Sixty-first session.

UN Economic and Social Council, 1996. Report of the Special Rapporteur Paul Hunt on the Right to everyone to the enjoyment of the highest attainable standard of physical and mental health.

UN Committee on Economic, Social and Cultural Rights (CESCR), 2000. General Comment No. 14: The Right to the Highest Attainable Standard of Health, 11 August 2000, E/C.12/2000/4,

UN Office of the High Commissioner for Human Rights (OHCHR), Fact Sheet No. 31, The Right to Health, June 2008, No. 31.

Vaigè, L. 2013. The concept of domestic violence in Lithuania and the aspect of gender from the perspective of international law. Socialinių mokslu studijos/Societal Studies. 2013, 5(1), p. 255-274.

Valiulienè v. Lithuania, ECHR, Strasbourg, No. 33234/07, 26 March 2013.

Venckevičienè, J., Čepas, A. (2013) Konfliktai ir smurtas artimoje aplinkoje. Ar įmanoma susitarti? Arba ką gali mediacija? (Conflicts and violence in domestic environment. Is it possible to reconcile? What can mediation do?) $\begin{array}{llll}\text { Mano } & \text { sveikata, } & \text { gruodžio } & \end{array}$ http://www.manosveikata.lt/lt/aktualijos/naujienos/konfliktai-ir-smurtasartimoje-aplinkoje-ar-imanoma-susitarti-arba-ka-gali-mediacija. Last accessed 2015-05-23. 
WAVE. 2012. Monitoring and Evaluating Health-Sector Initiatives to End Gender-based Violence. Suggestions for Health Professionals, Service Providers and Policy Makers in Eastern Europe and Central Asia. Available athttp://www.health-genderviolence.org/ . Last accessed 2015-12-19.

WHO. 2005. Multi-country study on women's health and domestic violence against women: initial results on prevalence, health outcomes and women's responses. Authors: Claudia García et al. Available at http://www.who.int/gender/violence/who_multicountry_study/Chapter10Chapter11.pdf?ua=1 last accessed 2016-01-20.

WHO. 2013. Global and regional estimates of violence against women. Clinical and policy guidelines. ISBN 9789241564625. .

WHO. 2014. Strengthening the role of the health system in addressing violence, in particular against women and girls, and against children. Sixtyseventh World Health Assembly. A67/A/CONF./1/Rev.1. WHO. 2015. Second WHO Discussion Paper (version dated 31 August 2015). Global plan of action to strengthen the role of the health system in addressing interpersonal violence, in particular against women and girls, and against children.

$X$ and $Y v$ Georgia, 25 August 2015, CEDAW/C/61/D/24/2009. 